\title{
PRETREATMENT WITH COLISTIN AND PROTEUS SENSITIVITY TO OTHER AGENTS
}

\author{
D. G. Chapman and A. D. Russell \\ Welsh School of Pharmacy, University of Wales Institute of Science \\ and Technology, Cathays Park, Cardiff CF1 3NU, Great Britain
}

(Received for publication October 29, 1977)

\begin{abstract}
The effects of pretreatment with colistin (polymyxin E) on the sensitivity of Proteus mirabilis, $P$. vulgaris and $P$. morganii strains to tris and sodium deoxycholate (DOC) have been studied. Pretreatment of two P. mirabilis strains (NCTC 60 and 4199) with low concentrations $(0.25 \sim 1 \mu \mathrm{g} / \mathrm{ml})$ of colistin rendered them sensitive to lysis by tris $(0.05 \mathrm{M})$ or DOC $(250 \sim 1,000 \mu \mathrm{g} / \mathrm{ml})$ although DOC induced lysis of control (non colistin-treated) suspensions also. In contrast, the other $P$. mirabilis strains, as well as the $P$. vulgaris and $P$. morganii strains were little affected by tris $(0.2 \mathrm{M})$ or DOC $(10,000 \mu \mathrm{g} / \mathrm{ml})$ even after exposure of the cells to high colistin concentrations (up to $500 \mu \mathrm{g} / \mathrm{ml}$ ). Colistin-pretreated or control cells of $P$. mirabilis NCTC 60 rapidly lost viability when suspended in water but not when held in 0.16 м sodium chloride solution. Ethylenediamine tetraacetate-pretreated cells of stra ns 60 and 4199 were fairly sensitive to tris, although the extent of the lysis was less than when colistin was used as pretreating agent. One strain of $P$. vulgaris (NCTC 4175) became sensitive to tris and to DOC following exposure of the cells to ampicillin.
\end{abstract}

Cells of Proteus mirabilis, $P$. vulgaris and $P$. morganii are resistant to polymyxins although recent reports indicate that these antibiotics have some effect on the outer layers of $P$. mirabilis cells. ${ }^{1 \sim 3)}$ It is likely that, following interaction with the cell wall of sensitive bacteria, the polymyxins act by damaging the cytoplasmic membrane. ${ }^{4 \sim 6)}$ Apart from Proteus sp., only Serratia marcescens among the Enterobacteriaceae is resistant to polymyxins, and it has been demonstrated with both types of organisms that synergism between a polymyxin and a sulphonamide can occur. ${ }^{{ }^{79}}{ }^{9}$

In this paper, we have investigated the effects of pretreatment of the cells of various strains of Proteus sp. in relation to their subsequent sensitivity to other agents, particularly tris and sodium deoxycholate.

\section{Materials and Methods}

\section{Bacterial Strains}

The following strains of Proteus sp. were obtained from the National Collection of Type Cultures, London: $P$. vulgaris strains 4175, 4635 and 4636; $P$. morganii strains 232, 235 and 1707; and $P$. mirabilis strains 60, 2896 and 4199.

Growth and Pretreatment Methods

Ten $\mathrm{ml}$ of an 18-hour culture, grown in nutrient broth (Oxoid) at $37^{\circ} \mathrm{C}$ was added to $90 \mathrm{ml}$ of broth and incubated in a shaking water-bath at 80 oscillations $\min ^{-1}$ for 2 hours at $37^{\circ} \mathrm{C}$. Sufficient of an antibacterial agent (colistin, chlorhexidine or cetrimide) was added, and incubation continued for 1 hour at $37^{\circ} \mathrm{C}$. Washed suspensions were then prepared as described below. In other experiments, cells were pretreated with ampicillin (at $1 / 2 \times$ the minimum inhibitory concentration).

In pretreatment studies involving ethylenediamine tetraacetic acid (EDTA), an overnight culture

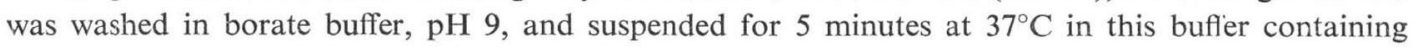
$0.01 \mathrm{M}$ EDTA. Washed suspensions were then prepared as described below. 
Preparation of Washed Suspensions

The log-phase culture, pretreated with a drug if necessary, or EDTA-treated suspension was divided into 5 aliquots, centrifuged at $19,000 \times g$ for 30 minutes and the cell suspensions triple washed with sterile saline $(0.16 \mathrm{M})$ and then dispersed in tris buffer $(0.05 \sim 0.2 \mathrm{M})$ of various $\mathrm{pH}$ values at $37^{\circ} \mathrm{C}$ or in sodium deoxycholate (DOC) in $0.16 \mathrm{M}$ saline at $37^{\circ} \mathrm{C}$. Optical density (O.D.) and viability changes were measured as described below.

Osmotic Shock

P. mirabilis NCTC 60 was grown for 3 hours at $37^{\circ} \mathrm{C}$ with shaking in broth (with or without 50 $\mu \mathrm{g} / \mathrm{ml}$ colistin for the final hour). The suspension was centrifuged at $19,000 \times g$ and triple washed with $0.16 \mathrm{~m}$ sodium chloride and then resuspended in either $0.16 \mathrm{~m}$ sodium chloride, $\mathrm{pH} 7.4$, or glassdistilled water, $\mathrm{pH}$ 7.1. During subsequent storage, samples were removed and serially diluted in $0.16 \mathrm{M}$ saline for viable counting by the surface-viable method, colony counts being made after incubation of plates for 24 hours at $37^{\circ} \mathrm{C}$.

Culture Media

Control and colistin-pretreated suspensions were streaked on to agar ( \pm DOC), ENDO agar, EMB agar, deoxycholate agar and MACCONKEY agar. Plates were incubated at $37^{\circ} \mathrm{C}$ for 24 hours and examined.

Optical Density (O.D.) Measurements

These were carried out at $500 \mathrm{~nm}$ in a Unicam SP 600 spectrophotometer using $1-\mathrm{cm}$ cells and an appropriate blank.

Viable Counting

Viable counts were made in triplicate on to overdried nutrient agar plates. Colonies were counted after incubation of the plates for 24 hours at $37^{\circ} \mathrm{C}$.

Chemicals

These were: ampicillin sodium B.P. (Beecham Research Laboratories, Brentford); benzalkonium chloride $(50 \%$ w/v solution, B.P.C.: Berk Pharmaceuticals, Godalming); cetrimide, B.P. (Glover's Chemicals, Leeds); chlorhexidine acetate, B.P.C. (I.C.I. Ltd., Macclesfield); colistin sulphomethate sodium (Pharmax, Ltd., Bexley); disodium EDTA and sodium chloride, both 'Analar' grade (B.D.H. Chemicals, Poole); sodium deoxycholate (pure grade, Koch-Light Laboratories, Colnbrook); tris(hydroxymethyl)-methylamine (referred to as Tris), Triton X-100 (scintillation grade) and Tween (polysorbate) 80 (all from B.D.H. Chemicals, Ltd.).

Minimum Inhibitory Concentration (MIC)

A washed suspension ( $c a .10^{6}$ viable cells $/ \mathrm{ml}$ ), $0.04 \mathrm{ml}$ was dropped on to previously dried (4 hours, $37^{\circ} \mathrm{C}$ ) nutrient agar plates containing an appropriate drug concentration. The plates were examined for the presence and absence of growth after incubation for 24 hours at $37^{\circ} \mathrm{C}$ and the MIC (the lowest drug concentration which completely prevented growth) determined.

\section{Results}

\section{MIC Values}

The MIC values of colistin, tris, DOC and ampicillin against the various strains are depicted in Table 1, which indicates the high resistance of strains to colistin and to DOC. In subsequent experiments, colistin was used in the range $0.125 \sim 500 \mu \mathrm{g} / \mathrm{ml}$, tris $0.05 \sim 0.2 \mathrm{M}$ and DOC $125 \sim 10,000 \mu \mathrm{g} / \mathrm{ml}$.

Pretreatment with Colistin

Pretreatment of $P$. mirabilis strains 60 and 4199 with $50 \mu \mathrm{g} / \mathrm{ml}$ of colistin rendered the cells susceptible to $0.05 \mathrm{M}$ tris (Fig. $1 \mathrm{a}, \mathrm{c}$; Table 2); the degree and extent of the lethal effect of tris against the pre-treated cells was $\mathrm{pH}$ dependent being slower at $\mathrm{pH} 8.5$, and more so at lower $\mathrm{pH}$ values, than at pH 9. Control cells (not pretreated with colistin) were insusceptible to tris at any $\mathrm{pH}$. Decreasing the colistin concentrations to as low as $1 \mu \mathrm{g} / \mathrm{ml}$ (strain 60: Fig. 1b) or $0.25 \mu \mathrm{g} / \mathrm{ml}$ (strain 4199: Fig. 1d) 
Table 1. MIC values for colistin and other substances

\begin{tabular}{c|c|c|c|c|c}
\hline Organism & $\begin{array}{c}\text { Strain } \\
\text { (N.C.T.C.) }\end{array}$ & $\begin{array}{c}\text { Colistin } \\
(\mu \mathrm{g} / \mathrm{ml})\end{array}$ & $\begin{array}{c}\text { Tris } \\
(\mathrm{M})\end{array}$ & $\begin{array}{c}\text { DOC } \\
(\mu \mathrm{g} / \mathrm{ml})\end{array}$ & $\begin{array}{c}\text { Ampicillin } \\
(\mu \mathrm{g} / \mathrm{ml})\end{array}$ \\
\hline \multirow{2}{*}{ P. mirabilis } & 60 & $>1,000$ & 0.25 & $>4,000$ & 1 \\
& 2896 & $>1,000$ & 0.25 & $>4,000$ & 16 \\
P. vulgaris & 4199 & $>1,000$ & 0.25 & $>4,000$ & 2 \\
& 4175 & $>1,000$ & 0.25 & $>4,000$ & 6 \\
P. morganii & 4635 & $>1,000$ & $\mathrm{Nd}$ & $\mathrm{Nd}$ & 8 \\
& 4636 & $>1,000$ & $\mathrm{Nd}$ & $\mathrm{Nd}$ & $>100$ \\
& 232 & $>1,000$ & 0.25 & $>4,000$ & 4 \\
\hline
\end{tabular}

Nd: not done

resulted in lysis on exposure of the treated cells to tris.

In contrast, pretreatment with colistin (50 $500 \mu \mathrm{g} / \mathrm{ml}$ ) did not render the cells of the other strains markedly sensitive to $0.05 \sim 0.2 \mathrm{M}$ tris at any $\mathrm{pH}$; the decrease in O.D. was always $<10 \%$ and the decrease in viability was correspondingly small and not dissimilar to control cells exposed to tris (Table 2). It is noteworthy that the third strain of $P$. mirabilis tested, 2896, shows a completely different response from strains 60 and 4199. Other strains (not described) of $P$. mirabilis tested resembled strain 2896.

The effects of pretreatment of cell suspensions with colistin on their subsequent sensitivity to DOC in saline are shown in Figs. 2 and 3 and Tables 3 and 4. P. mirabilis strains 60 and 4199 were highly sensitive to DOC irrespective of whether or not they had been pretreated with colistin, although the antibiotic did increase the rate of DOC-induced death (Tables 3 and 4). However, the other strains (Table 4) plus additional strains (not described) of the 3 species did not become sensitive to DOC even after the cells had been exposed to colistin.

Control and colistin-pretreated suspensions were plated on to various media: irrespective of pretreatment or not, colony counts of strains 232, 2896 and 4175 were not inhibited by nutrient agar containing $1,000 \mu \mathrm{g} / \mathrm{ml}$ DOC, or by ENDO, EMB, MACCONKEY or deoxycholate citrate agar media. In contrast, cells of strains 60 and 4199 which had or had not been pre-exposed to colistin grew on all media except EMB agar where colony growth was completely inhibited.

Cell suspensions which had been exposed or unexposed (controls) to colistin were tested for their sensitivity to a range of concentrations of the non-ionic surface-active agents, polysorbate (Tween) 80 
Table 2. Effect of tris (pH 9) on Proteus strains at $37^{\circ} \mathrm{C}$

\begin{tabular}{|c|c|c|c|c|c|c|}
\hline \multirow{2}{*}{$\begin{array}{l}\text { Colistin } \\
\text { pretreatment }\end{array}$} & \multirow{2}{*}{$\begin{array}{l}\text { Time (min) after } \\
\text { exposure to tris }\end{array}$} & \multicolumn{5}{|c|}{ Proteus strain* } \\
\hline & & 60 & 4199 & 2896 & 4175 & 232 \\
\hline \multirow{5}{*}{ No } & 0 & 100 & 100 & 100 & 100 & 100 \\
\hline & 10 & 86 & 82 & 90 & 90 & 100 \\
\hline & 20 & 78 & 76 & 83 & 84 & 95 \\
\hline & 30 & 74 & 72 & 78 & 78 & 87 \\
\hline & 60 & 70 & 70 & 74 & 77 & 82 \\
\hline \multirow{5}{*}{$\mathrm{Yes}^{+}$} & 0 & 100 & 100 & 100 & 100 & 100 \\
\hline & 10 & 30 & 29 & 86 & 86 & 90 \\
\hline & 20 & 21 & 14 & 81 & 80 & 84 \\
\hline & 30 & 15 & 10 & 69 & 72 & 76 \\
\hline & 60 & 0.5 & 0.38 & 61 & 67 & 70 \\
\hline
\end{tabular}

Figures are $\%$ surviving cells $(0 \mathrm{~min}=100 \%)$ after exposure to tris.

* Strains 60,4199 and 2896 are $P$. mirabilis; 4175 is $P$. vulgaris; 232 is $P$. morganii.

$+50 \mu \mathrm{g} / \mathrm{ml}$ colistin for strains 60 and $4199 ; 500 \mu \mathrm{g} / \mathrm{ml}$ colistin for strains 2896,4175 and 232.

Table 3. Susceptibility of $P$. mirabilis 60 to $\mathrm{DOC}$ in $0.16 \mathrm{M}$ saline at $37^{\circ} \mathrm{C}$

\begin{tabular}{c|r|r|r|r}
\hline \multirow{2}{*}{$\begin{array}{c}\text { Colistin pretreatment } \\
(50 \mu \mathrm{g} / \mathrm{ml})\end{array}$} & $\begin{array}{c}\text { Time }(\mathrm{min}) \text { after } \\
\text { exposure to DOC }\end{array}$ & 125 & 250 & 500 \\
\cline { 3 - 4 } & 0 & 100 & 100 & 100 \\
& 10 & 94 & 84 & 14 \\
No & 92 & 82 & 10.2 \\
& 30 & 84 & 70 & 9.8 \\
& 60 & 79 & 70 & 6.2 \\
\hline & 0 & 100 & 100 & 100 \\
& 10 & 94 & 60 & 5 \\
& 20 & 91 & 56 & 1.1 \\
& 30 & 80 & 50 & 0.8 \\
\hline
\end{tabular}

* $0 \mathrm{~min}=100 \%$

Cells which were pretreated with colistin $(50 \mu \mathrm{g} / \mathrm{ml})$ and then held in $0.16 \mathrm{M}$ saline (DOC absent) at $37^{\circ} \mathrm{C}$ showed no decrease in viability.

Table 4. Summary of susceptibility of other Proteus strains to DOC in $0.16 \mathrm{~m}$ saline at $37^{\circ} \mathrm{C}$

\begin{tabular}{|c|c|c|c|c|}
\hline \multirow{2}{*}{ Organism } & \multirow{2}{*}{$\begin{array}{l}\text { Colistin pretreatment } \\
\quad(500 \mu \mathrm{g} / \mathrm{ml})^{* *}\end{array}$} & \multicolumn{3}{|c|}{$\%$ Viability* after exposure for $60 \mathrm{~min}$ to DOC $(\mu \mathrm{g} / \mathrm{ml})$} \\
\hline & & 125 & 250 & $1,000^{+}$ \\
\hline P. mirabilis 2896 & $\begin{array}{l}\text { No } \\
\text { Yes }\end{array}$ & $\begin{array}{l}92 \\
91\end{array}$ & $\begin{array}{l}88 \\
86\end{array}$ & $\begin{array}{l}72 \\
70\end{array}$ \\
\hline P. vulgaris 4175 & $\begin{array}{l}\text { No } \\
\text { Yes }\end{array}$ & $\begin{array}{l}89 \\
86\end{array}$ & $\begin{array}{l}88 \\
82\end{array}$ & $\begin{array}{l}68 \\
58\end{array}$ \\
\hline P. morganii 232 & $\begin{array}{l}\text { No } \\
\text { Yes }\end{array}$ & $\begin{array}{l}91 \\
90\end{array}$ & $\begin{array}{l}76 \\
75\end{array}$ & $\begin{array}{l}62 \\
58\end{array}$ \\
\hline P. mirabilis 4199 & $\begin{array}{l}\text { No } \\
\text { Yes }\end{array}$ & $\begin{array}{l}76 \\
70\end{array}$ & $\begin{array}{l}62 \\
41\end{array}$ & $\begin{array}{l}4.8 \\
0.34\end{array}$ \\
\hline
\end{tabular}

* Viability at $0 \mathrm{~min}=100 \%$

+ With strains 2896,4175 and 232, concentrations of DOC up to $10 \mathrm{mg} / \mathrm{ml}$ were no more effective against colistin-treated cells than against control suspensions.

** $50 \mu \mathrm{g} / \mathrm{ml}$ when $P$. mirabilis 4199 tested. 
Fig. 2. Susceptibility to DOC in saline of colistin-pretreated cells of $P$. mirabilis 60 (very similar results were obtained with strain 4199).

(a) control (not pretreated with colistin), (b) cells pretreated with $50 \mu \mathrm{g} / \mathrm{ml}$ colistin.

(a)

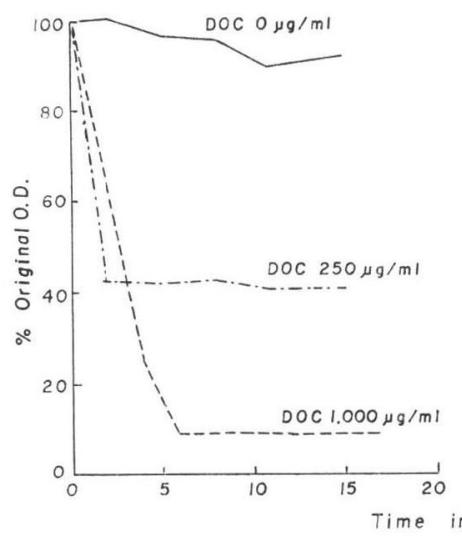

Fig. 3. Susceptibility to DOC in saline of colistinpretreated cells of $P$. morganii 232.

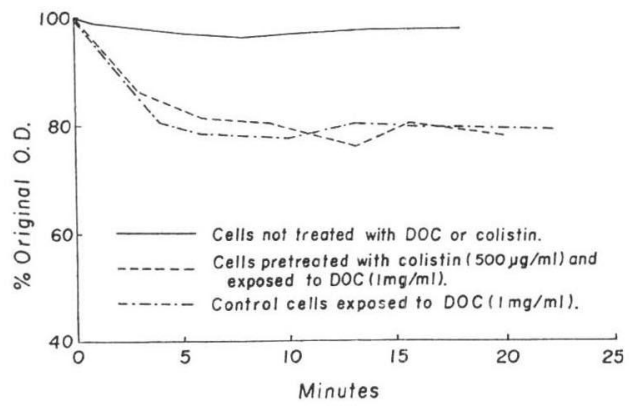

(b)

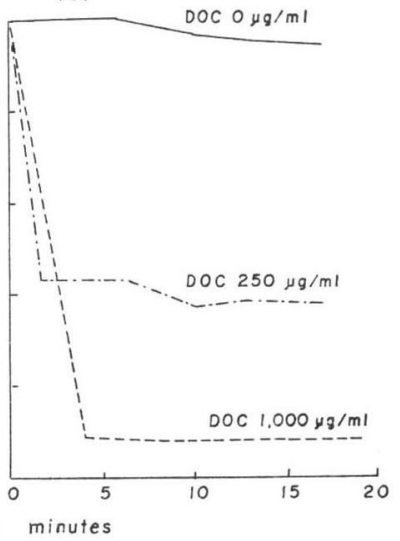

Fig. 4. Susceptibility to DOC in saline of ampicillinpretreated cells of $P$. vulgaris 4175 .

(Untreated cells were not lysed by $1,000 \mu \mathrm{g} / \mathrm{ml}$ DOC).

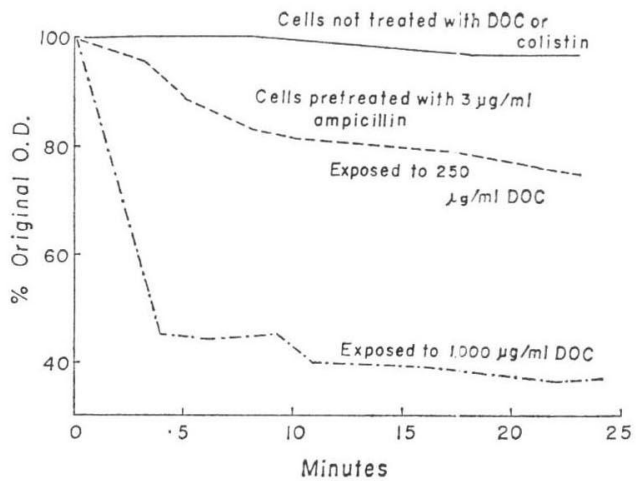

and Triton X-100, and to EDTA (0.01 M, pH 9). In no instance did cell lysis occur.

Control or colistin-pretreated cells of $P$. mirabilis NCTC 60 rapidly lost viability when suspended in water but not when held in $0.16 \mathrm{M}$ sodium chloride solution.

\section{Pretreated with Other Agents}

Pretreatment of cell suspensions with EDTA $(0.1 \mathrm{M}, \mathrm{pH} 9)$ for 5 minutes at $37^{\circ} \mathrm{C}$ did not render the cells susceptible to colistin $(1,000 \mu \mathrm{g} / \mathrm{ml})$. However, such pretreated cells of strairls 60,4199 and to a lesser extent, 2896, became rather more sensitive to tris; the extent of this sensitivity was less than with colistin-pretreated cells.

Pretreatment of cell suspensions with $200 \mu \mathrm{g} / \mathrm{ml}$ cetrimide for 60 minutes did not increase the sensitivity of the organisms to tris $(\mathrm{pH} 9)$ or DOC. Likewise, chlorhexidine $(2.5 \mu \mathrm{g} / \mathrm{ml})$-prereated $P$. mirabilis 60 was not rendered sensitive to tris $(0.05 \mathrm{M}, \mathrm{pH} 9)$.

Pretreatment of cells with ampicillin (at $1 / 2 \times$ the respective M.I.C.) and subsequent exposure to tris or DOC gave the following results:

(1) tris: some lysis of $P$. mirabilis strains 60 and 4199 occurred with $0.05 \mathrm{M}$ tris at pH 9 and of 
$P$. mirabilis 2896, $P$. vulgaris 4175 and $P$. morganii 232 with $0.2 \mathrm{M}$ tris at $\mathrm{pH} 9$;

(2) DOC: strains 60 and 4199 were rapidly lysed by DOC concentrations of $250 \sim 1,000 \mu \mathrm{g} / \mathrm{ml}$ (vide above also). Strains 232 and 2896 showed some lysis after exposure to $1,000 \mu \mathrm{g} / \mathrm{ml} \mathrm{DOC}$ (decreases in O.D. over a 25 -minute period were, respectively, $18 \%$ and $30 \%$ ), whereas considerably more lysis of $P$. vulgaris 4175 was observed (Fig. 4).

\section{Discussion}

Proteus sp. are highly resistant to polymyxins $\mathrm{s}^{1,2,10)}$ and this is borne out by the results in Table 1 . The reasons for this high resistance are still unclear. Sud and FEINGold ${ }^{1)}$ have proposed that the composition of the envelope lipid is not responsible, but rather the accessibility of the lipids to these drugs, since polymyxins are known to interact with phosphate groups of phospholipids in the cytoplasmic membrane ${ }^{4,11)}$. Combinations of polymyxin with a sulphonamide are active against Proteus $\mathrm{sp.}^{{ }^{7}{ }^{9)}}$ and polymyxin B renders the cells of $P$. mirabilis sensitive to tris, DOC and osmotic shock ${ }^{2}$. It is not clear from the work of SUD and FEINGOLD ${ }^{2)}$, however, whether they found this effect with only one strain; moreover, only one concentration $(20 \mu \mathrm{g} / \mathrm{ml})$ of polymyxin B in liquid medium was apparently tested.

Of the nine strains of Proteus sp. tested in the present paper, only two became sensitive to tris; these two were sensitive to DOC irrespective of whether or not they had been pretreated with colistin. Thus, it seems likely that very significant differences must exist in the outer envelope layers between these two strains (60 and 4199) on the one hand and the remaining strains on the other. Studies with EDTA indicate the comparative resistance of all strains to this chelating agent, and thus differences between the strains are unlikely to be in the context of the cation composition of the envelope.

Polymyxins interact with the outer layers of Pseudomonas aeruginosa, ${ }^{4)}$ although damage is believed to result from their effect on the cytoplasmic membrane. This interaction with the outer layers may take place between the antibiotic and wall phospholipid ${ }^{12)}$ and/or with lipopolysaccharide ${ }^{13,14)}$. Preliminary studies in this laboratory suggest that differences in envelope phospholipid may be responsible for the variations in strain response to colistin and that whilst some alternation to this phospholipid may occur in strains 60 and 4199, the cells still remain resistant to the lethal action of the antibiotic because insufficient of the drug is able to reach the cytoplasmic membrane. This alteration to the envelope could, however, be sufficient to render these cells susceptible to tris and osmotic shock. Cells of strains 60 and 4199 are susceptible in liquid suspension to DOC, and rather more so after they have been exposed to colistin (Tables 3 and 4). Lipopolysaccharide is broken into small fragments by $\mathrm{DOC}^{15)}$, but whether the present results indicate this to occur in whole cells is unproven.

SUD and FEINGOLD ${ }^{2)}$ have been shown that, following removal of the polymyxin, cell sensitivity to normally harmless agents is soon lost, and the results in this paper support this finding.

Pretreatment of cells with cetrimide or chlorhexidine did not increase the sensitivity of the organisms to tris ( $\mathrm{pH} 9)$ or DOC. In view of the findings of SULING and O'LEARY ${ }^{16)}$, it is possible that both the surfactant and the other agent must be present at the same time for any synergistic action to occur.

Pretreatment of cells with ampicillin led to extension lysis of $P$. vulgaris 4175 on exposure to DOC $(1 \mathrm{mg} / \mathrm{ml})$. BURMAN and colleagues ${ }^{17)}$ using cholate concentrations of $3 \sim 15 \mathrm{mg} / \mathrm{ml}$, generally, have found that ampicillin-treated cells of some Gram-negative strains are lysed by the cholate because of a distortion of the cytoplasmic membrane. Their proposal that the murein sacculus is either a part of the penetration barrier or is responsible for holding together the outer membrane structure could be relevant to this particular strain and to a lesser extent to the other strains.

\section{References}

1) Sud, I. J. \& D. S. FeIngold: Mechanism of polymyxin B resistance in Proteus mirabilis. J. Bact. 104: 289 294, 1970

2) Sud, I. J. \& D. S. FeIngold: Effect of polymyxin B on antibiotic-resistant Proteus mirabilis. Antimicr. Agents \& Chemoth. 1: $417 \sim 421,1972$ 
3) Feingold, S. D.; C. C. Hsuchen \& I. J. Sud: Basis for the selectivity of action of the polymyxin antibiotics on cell membranes. Ann. N.Y. Acad. Sci. 235: 480 492, 1974

4) Newton, B. A.: The properties and mode of action of the polymyxins. Bact. Rev. 20: 14 27, 1956

5) Schindler, P. R. G. \& M. Teuber: Action of polymyxin B on bacterial membranes: morphological changes in the cytoplasm and in the other membrane of Salmonella typhimurium and Escherichia coli B. Antimicr. Agents \& Chemoth. 8: 95 104, 1975

6) Teuber, M. \& J. BAder: Action of polymyxin B on bacterial membranes: phosphatidylglycerol - and cardiolipin - induced susceptibility to polymyxin B in Acholeplasma laidlawii B. Antinicr. Agents \& Chemoth. 9: 26 35, 1976

7) Russell, F. E.: Synergism between sulphonamide drugs and antibiotics of the polymyxin group against Proteus species in vitro. J. Clin. Path 16: 362 366, 1963

8) Quesnel, L. B. \& P. S. HANDley: Synergism between polymyxins, polysorbate and animetabolites of folic acid synthesis, and a paper disc technique for routine testing for synergism. Microbios 10: 199 210, 1974

9) Handley, P. S.; L. B. Quesnel \& M. M. Sturgiss: Uitrastructural changes produced in Proteus vulgaris by a synergistic combination of colistin and sulphadiazine. Microbios 10: $211 \sim 223,1974$

10) Sud, I. J. \& D. S. FeINGold: Detection of agents that alter the bacterial cell surface. Antimicr. Agents \& Chemoth. 8: $34 \sim 37,1975$

11) Few, A. G.: The interaction of polymyxin $\mathrm{E}$ with bacterial and other lipids. Biochim. Biophys. Acta 16: $137 \sim 145,1955$

12) Brown, M. R. W. \& S. M. Wood: Relation between cation and lipid content of cell walls of Pseudomonas aeruginosa, Proteus vulgaris and Klebsiella aerogenes and their sensitivity of polymyxin B and other antibacterial agents. J. Pharm. Pharmac. 24: 215 218, 1972

13) Teuber, M.: Action of polymyxin B on bacterial membranes. II. Formation of lipophilic complexes with phosphatidic acid and phosphatidylglycol. Z. Naturforsch. 26: 476 477, 1973

14) Tsang, J. C.; D. A. Weber \& D. A. Brown: Evidences for complex formation between polymyxin B and lipopolysaccharides from Serratia marcescens. J. Antibiotics 29: 735 742, 1976

15) Ribi, E.; R. L. Anacker, R. Brown, W. T. Haskins, B. Malmgren, K. C. Milner \& J. A. Rudbach: Reaction of endotoxins and surfactants. I. Physical and bioıgical properties of endotoxin treated with sodium deoxycholate. J. Bact. 92: 1493 1509, 1958

16) Suling, W. J. \& W. M. O'Leary: Effect of surfactants on antibiotic resistance. Anti nicr. Agents \& Chemoth. 8: $334 \sim 343,1975$

17) Burman, L. G.; K. Nordstrom \& G. D. Bloom: Murein and the outer penetration barricr of Escherichia coli K-12, Proteus vulgaris and Pseudomonas aeruginosa. J. Bact. 112: $1364 \sim 1374,1972$ 